Document downloaded from:

http://hdl.handle.net/10251/141439

This paper must be cited as:

Bouzas Blanco, A.; Martí Ortega, N.; Grau, S.; Barat, R.; Mangin, D.; Pastor Alcañiz, L. (2019). Implementation of a global P-recovery system in urban wastewater treatment plants. Journal of Cleaner Production. 227:130-140. https://doi.org/10.1016/j.jclepro.2019.04.126

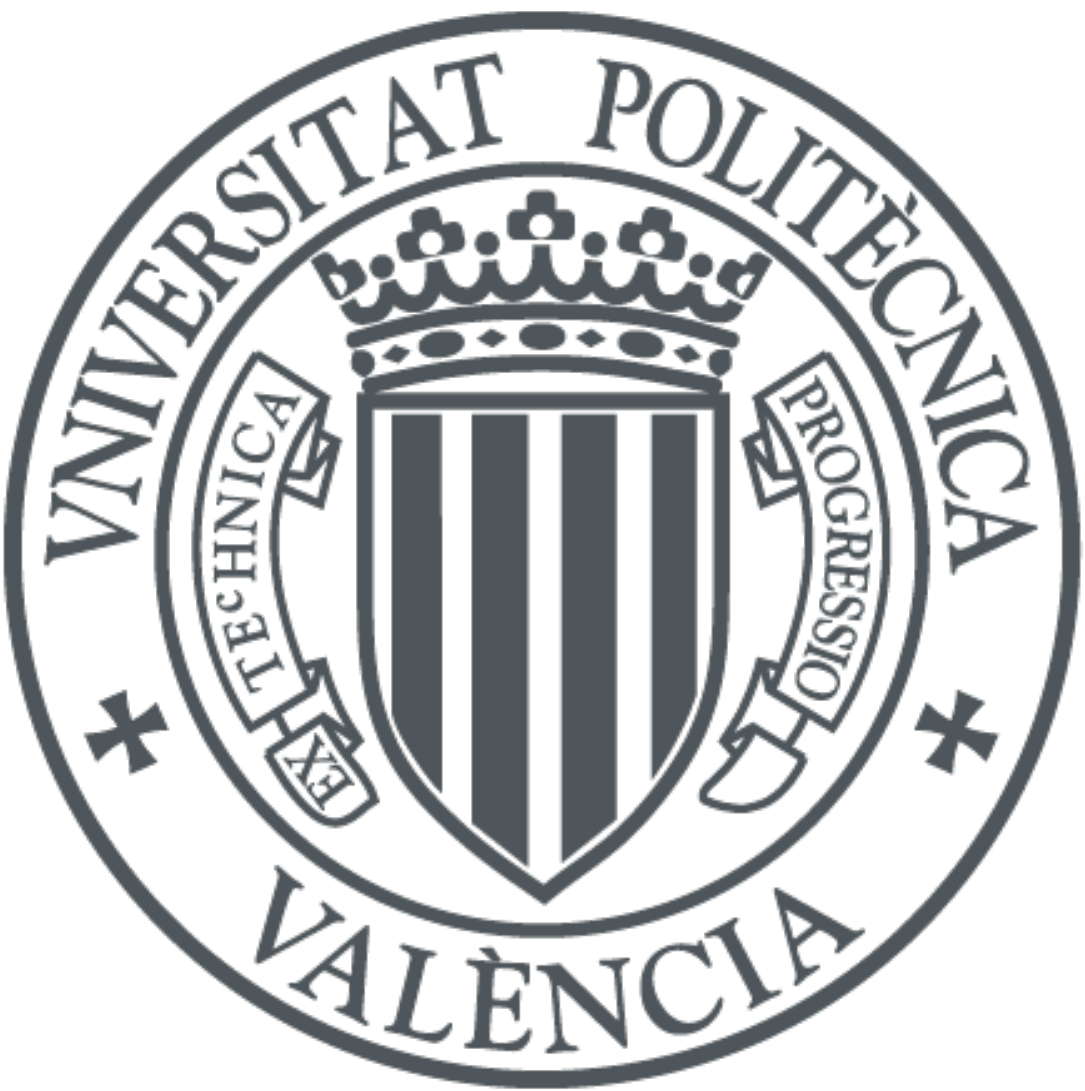

The final publication is available at

https://doi.org/10.1016/j.jclepro.2019.04.126

Copyright Elsevier

Additional Information 


\title{
Implementation of a global P-recovery system in urban wastewater treatment plants
}

\author{
A. Bouzas*, N. Martí*, S. Grau** R. Barat***, D. Mangin, **** L. Pastor**, \\ * CALAGUA - Unidad Mixta UV-UPV, Departament d'Enginyeria Química, Universitat de València, \\ Avinguda de la Universitat s/n, 46100 Burjassot, Valencia, Spain (alberto.bouzas@uv.es, \\ nuria.marti@uv.es) \\ **Depuración de Aguas del Mediterráneo (DAM). Avenida Benjamín Franklin, 21. 46980 Parque \\ Tecnológico, Paterna, Valencia, Spain (laura.pastor@dam-aguas.es, sofia.grau@dam-aguas.es) \\ *** CALAGUA - Unidad Mixta UV-UPV, Institut Universitari d'Investigació d'Enginyeria de l'Aigua \\ i Medi Ambient - IIAMA, Universitat Politècnica de Valencia, Camí de Vera s/n, 46022 Valencia, \\ Spain (rababa@dihma.upv.es) \\ **** Univ Lyon, Université Claude Bernard Lyon 1, CNRS, LAGEP UMR 5007, 43 boulevard du 11 \\ novembre 1918, F-69100, Villeurbanne, France (denis.mangin@univ-lyon1.fr)
}

Corresponding author: A. Bouzas. Tel.: +34-963544541; e-mail address: alberto.bouzas@uv.es

\begin{abstract}
Current wastewater treatment plants (WWTPs) paradigm is moving towards the so-called water resource recovery facilities in which sewage is considered a source of valuable resources. In particular, urban WWTPs are crucial systems to enhance phosphorus $(\mathrm{P})$ recycling. This paper evaluates the implementation of a P-recovery system in Calahorra WWTP combining the operation of a new sludge line configuration coupled to a struvite crystallisation reactor at demonstration-scale. This new configuration consisted in the elutriation in the gravity thickener of the mixed sludge contained in the mixing chamber in order to reduce the phosphate load to the anaerobic digestion. The results indicated that the $\mathrm{P}$ available in the primary sludge overflow was nearly five times more than the obtained for the conventional configuration (1.88 vs. $0.39 \mathrm{gP} / \mathrm{kg}$ sludge treated), and the uncontrolled P precipitation inside the anaerobic digester was reduced by $43 \%$. Regarding the total $\mathrm{P}$ entering the WWTP, $19 \%$ of the total P could be recovered with the new configuration proposed in comparison with $9 \%$ in the previous conventional configuration. The average recovery efficiency in the crystallisation plant was $86.9 \pm 0.4 \%$, yielding a struvite recovery of $8.0 \pm 0.6 \mathrm{~kg} / \mathrm{d}\left(0.67 \pm 0.04 \mathrm{~kg} / \mathrm{m}^{3} \mathrm{fed}\right.$ to the crystalliser). The potential struvite production with the new configuration would be around 41 $\mathrm{kg} / \mathrm{d}(15 \mathrm{t} / \mathrm{y})$ crystallising the thickener supernatant which could be increased up to around $103 \mathrm{~kg} / \mathrm{d}$ (38 $\mathrm{t} / \mathrm{y}$ ) treating all the P-enriched streams (thickener supernatant and centrate streams). The paper demonstrates that WWTPs can contribute to reduce P scarcity, resulting in environmental and economic benefits.
\end{abstract}

Keywords: crystallisation; global phosphorus recovery; sludge line management; struvite; urban WWTP.

\section{Introduction}

Phosphorus $(\mathrm{P})$ is a non-replaceable element widely used in fertiliser production. The dependency and scarcity of phosphate rocks and the increasing in population indicate the need for suitable intensification of agriculture, for which a sustainable supply of $\mathrm{P}$ is essential. Indeed, $\mathrm{P}$ has been classified as a critical raw material by the European Comission (EC, 2017). Commercial fertilisers depend on the availability of phosphate rock reserves (mainly located in a few countries such as China, USA, Morocco South Africa and Jordan) (Cieślik and Konieczka, 2017). Moreover, exhaustion of global reserves is expected to occur although the moment at which they will really deplete is still under discussion: from the less optimistic estimations of 50-60 years (Tao and $\mathrm{Xia}, 2007$ ) to the most optimistic ones of 200 years (Tan and Lagerkvist, 2011). Therefore, it is necessary to investigate alternatives for sustainable management of P- 
recycling considering cost-effective, energy efficient and environmental compatible (Kataki et al., 2016a; Kataki et al., 2016b).

Pollution problems such as eutrophication due to phosphorus release in wastewater effluents, requires the development of a sustainable management of this resource in wastewater treatment plants (WWTPs). Usually, the aim of WWTPs is to remove phosphate rather than recover it. However, several studies have increasingly recognized the interest of $\mathrm{P}$ recovery from wastewater as the latter provides rich sources for P recovery (Ye et al., 2017). In comparison to other wastewater streams, municipal wastewaters present the greatest potential for $\mathrm{P}$ recovery because of the large quantity of municipal wastewater produced despite containing small concentration of phosphates (Metha et al., 2015; Zhou et al., 2017). Hence, municipal WWTPs are crucial to enhancing the P recovery.

In recent years, a new WWTP paradigm based on the so-called water resource recovery facility (WRRF) concept has emerged for waste-to-resource recovery within the scientific community (Batstone et al., 2015; Seco et al., 2018). Within this paradigm, sewage is no longer considered as a waste but as a source of raw valuable resources, resulting in environmental and economic benefits (Puyol et al., 2017). Consequently, maximising resource recovery has become a key issue in the sewage treatment field (Beuckels et al., 2015).

In WWTPs with P removal chemically or biologically, approximately between 75$90 \%$ of the phosphorus entering the municipal WWTP is transferred into the sewage sludge (Tarayre et al., 2016; Martí et al., 2017). In WWTPs with Enhanced Biological Phosphorus Removal (EBPR), phosphates are removed from wastewater and accumulated inside the polyphosphate accumulating bacteria (PAO) as internal granules of polyphosphate (Poly-P). During the anaerobic digestion of the sludge, Poly-P is released to the liquid phase. Therefore, the rejected liquors from digested sludge dewatering show high phosphorus, ammonium and magnesium concentrations which make these streams very appropriate for recovering phosphorus as struvite $\left(\mathrm{MgNH}_{4} \mathrm{PO}_{4} \cdot 6 \mathrm{H}_{2} \mathrm{O}\right)$ in a crystallisation process (Pastor et al., 2010: Lahav et al., 2013). However, at this point of the sludge line, most of the soluble $P$ is lost due to precipitation in the anaerobic digester and post-digestion processes, which causes important maintenance problems in the WWTP (Parsons and Doyle, 2004; Barat et al., 2009; Martí et al., 2010). Thus, sludge management alternatives to reduce uncontrolled $\mathrm{P}$ precipitation must be evaluated to enhance $\mathrm{P}$ recovery in WWTPs and to reduce operating costs due to uncontrolled precipitation.

Phosphorus can be recovered from either wastewater, sewage sludge or sewage sludge ash, and a number of full-scale techniques are already operative (Cordell et al., 2011). Among them, phosphorus recovery by struvite crystallisation is one of the most promising technologies developed for treating sludge rejected streams (Cieślik and Konieczka, 2017; Huang et al., 2018). The product obtained, struvite, is a valuable slow release fertiliser for agriculture and can be sold at a profit. At present, product criteria for struvite are being studied to be used as a direct fertiliser or as a raw material for the fertiliser manufacturing. The final aim is to integrate struvite into the EU Fertiliser Regulation. Struvite can also be used as a raw material for chemical industry to produce food additives, chemical agents, structural products and fireretardant agents (Tao et al., 2016).

Another advantage of implementing this technology in WWTPs is connected with the prevention of uncontrolled spontaneous phosphorus precipitation in the sludge 
treatment line. Generally, the struvite crystallisation process is focused on P recovery in the dewatering stream after anaerobic digestion (Desmidt et al., 2015), which do not prevent scaling problems as above-mentioned. The implementation of a struvite recovery system before the anaerobic digester reduces scaling problems and enhances $P$ recovery. In a previous work (Martí et al., 2017), a new sludge line configuration for WWTPs involving EBPR and anaerobic digestion was proposed aiming at reducing uncontrolled $\mathrm{P}$ precipitation and at obtaining $\mathrm{P}$-rich streams to be used in a crystallisation process.

P-recycling by struvite crystallization is a well-known process which has been well studied at lab-scale (Pastor et al., 2008a; Pastor et al., 2008b; Lahav et al., 2013). However, there are currently few real applications at industrial scale due to gaps and shortcomings in this field such as process design, product quality and economic feasibility (Pearce, 2015; Li et al., 2019). This paper addresses these knowledge gaps by providing a proof of process design and evaluation of the technical feasibility of a global P-recovery system based on the operation of a new sludge line configuration coupled to a struvite crystallisation reactor at demonstration-scale.

\section{Material and Methods}

The study conducted in this paper was carried out at lab-scale and at industrial-scale. The following paragraphs summarises the methodology used in both types of studies.

2.1.Upgraded sludge line configuration

Figure 1 presents a flowchart of the optimal WWTP configuration proposed in Martí et al. (2017). The proposed sludge management operation tried to maximise the potential recovery of $\mathrm{P}$ as struvite by recirculating and elutriating the mixed sludge of the mixing chamber into the gravity thickener. Thus, two streams with high $\mathrm{P}$ concentration, which could be used in a crystallisation process, are obtained: the primary thickener supernatant and the centrifuge centrate.

The implementation of this configuration requires some minor structural modifications at the WWTPs, which consists in:

- The installation of a recirculation stream (i.e., elutriation flow) between the mixing chamber and the primary thickener to promote the phosphate extraction from the mixed sludge contained in the mixing chamber.

- The installation of a purge stream (i.e., digestion flow) to carry the mixed thickened sludge directly from the bottom of the primary thickener to the digester.

- Changes in the position of the current valves, pumps and frequency converters in order to adapt these devices to the new configuration.

These modifications were implemented in the Calahorra WWTP (La Rioja, Spain) which has $23000 \mathrm{~m}^{3} / \mathrm{d}$ of capacity and comprises A2/O configuration and anaerobic mesophilic digestion. The upgraded sludge line configuration was operated in manually mode for five months at a digestion flow between 74 and $98 \mathrm{~m}^{3} / \mathrm{d}$ and an elutriation flow between 48 and $122 \mathrm{~m}^{3} / \mathrm{d}$, leading to phosphate concentration peaks of up to $176 \mathrm{mg}$ P/L. However, under this operation mode and especially during rain events, the sludge blanket level in the primary thickener reached high values above $2.3 \mathrm{~m}$ (i.e., higher than $65 \%$ of the thickener depth) or even overloading the thickener in two occasions. 
In order to solve these operating problems, an algorithm based on fuzzy logic control was developed and implemented to control the elutriation process. The control strategy (Figure 2) helps on the management of the several stream flow rates (i.e., elutriation flow, digestion flow and primary sludge thickener-mixing chamber flow), and also the sludge blanket level in the primary sludge thickener (to prevent solids overflow) by means of an ultrasonic sensor (Pulsar Process Measurement®). Briefly, the control system consists in a feedback control of the measured sludge blanket level by manipulating the elutriation flow rate. Moreover, this control ensures the maximum phosphorus concentration in the primary sludge thickener supernatant enhancing the phosphorus recovery in the WWTP.

\subsection{Lab-scale crystallisation assays}

Preliminary crystallisation experimental studies with gravity thickener supernatant from Calahorra WWTP were performed at lab-scale once the elutriation system was implemented. This stream was selected for the study since the struvite crystallisation process is usually focused on the dewatering stream after anaerobic digestion (Desmidt et al., 2015). The aim of these experiments was to check how the thickener supernatant performed in a crystallising process and thus to obtain the required information for the scaling up of the crystallising reactor. Indeed, the kinetics of the different crystallisation mechanisms (primary and secondary nucleation, growth, agglomeration...) can be strongly affected by impurities present in the supernatants fed to the reactor. Moreover, the $\mathrm{pH}$ and $\mathrm{Mg} / \mathrm{P}$ or $\mathrm{Ca} / \mathrm{P}$ ratios in a thickener supernatant can notably differ from the ones observed in a dewatering centrate (Pastor et al., 2008b; Martí et al., 2010), affecting therefore the crystallisation efficiency.

The assays were performed in a $20.6 \mathrm{~L}$ crystallisation reactor consisting in a reaction zone, surmounted by a settling zone $(4.95 \mathrm{~L}$ and $15.6 \mathrm{~L}$, respectively) to keep the solid particles inside of the reactor. This design allowed operating the crystalliser in continuous mode with the liquid phase and batchwise with the solid particles. The reactor was outfitted with $\mathrm{pH}$ and temperature probes, connected to a data acquisition system. Further details of the lab-scale crystalliser can be found in Pastor et al., (2008a; 2010).

In order to achieve the desired $\mathrm{pH}$ in the lab crystalliser $(\mathrm{pH}=8.7)$, a $\mathrm{NaOH}$ solution $(0.3 \mathrm{M})$ was added. Software based on fuzzy logic control (Chanona et al., 2006) was used to maintain the $\mathrm{pH}$ at the set value. The hydraulic retention time (HRT) in the mixing zone was set initially at $4.35 \mathrm{~h}$ and was further decreased to $2.05 \mathrm{~h}$ and $1.05 \mathrm{~h}$ to assess this parameter. In order to satisfy the stoichiometric demand for struvite formation (i.e., $\mathrm{Mg}: \mathrm{P}=1: 1$ ), an extra dose of magnesium was added using a solution prepared with $\mathrm{MgCl}_{2} \cdot 6 \mathrm{H}_{2} \mathrm{O}$ (ca. $1600 \mathrm{mg} \mathrm{Mg}+2 / \mathrm{L}$ ).

\subsection{Analytical methods}

Total solids (TS), total volatile solids (TVS) and total P were analysed as indicated in the Standard Methods (APHA, 2012). Volatile fatty acids concentration (VFA) were measured in accordance with Moosbrugger et al. (1992). Soluble calcium $\left(\mathrm{Ca}^{2+}\right)$, magnesium $\left(\mathrm{Mg}^{2+}\right)$ and potassium $\left(\mathrm{K}^{+}\right)$were analysed by means of Atomic Absorption Spectrometry (AAS) (ICE 3000 SERIE S, Thermo Scientifics, Franklin, USA). Phosphate $\left(\mathrm{PO}_{4}-\mathrm{P}\right)$ and ammonium $\left(\mathrm{NH}_{4}-\mathrm{N}\right)$ concentrations were determined by applying Standard Methods (APHA, 2012) in a Smartchem 200 automatic analyser 
(Westco Scientific Instruments, Italy). The characterisation of the solids produced in the crystalliser was carried out applying the following methods:

\subsubsection{Particle size distribution analysis}

Particle size distribution was measured by using Mastersizer 2000 analyser (Malvern Instruments Ltd., United Kingdom). The appropriate reference index of refraction was selected and the background noise was measured for 10 seconds in the dispersing medium (water). About $0.5 \mathrm{~g}$ of sample was dispersed in $100 \mathrm{~mL}$ of water, maintaining agitation at 1800 r.p.m. The light scattering was measured for $10 \mathrm{~s}$. Dispersed sample was introduced into the laser scattering analyser. Data were acquired through the Mastersizer 2000 software measuring in the range $100 \mathrm{~nm}-$ $3 \mathrm{~mm}$.

\subsubsection{Metals}

Metals ( $\mathrm{Zn}, \mathrm{Cd}, \mathrm{Cr}, \mathrm{Cu}, \mathrm{Ni}$ and $\mathrm{Pb}$ ) were measured through Atomic Absorption Spectrometry (AAS) using ICE 3000 SERIE S analyser (Thermo Scientifics, Franklin, USA). An amount of $0.5 \mathrm{~g}$ of sample were dissolved in $50 \mathrm{~mL}$ of water and $5 \mathrm{~mL}$ of $\mathrm{HNO}_{3}$. Then, more water was added until a total volume up to $100 \mathrm{~mL}$. For $\mathrm{Mg}$ and $\mathrm{Ca}$ content determinations, lanthanum was added to a final concentration of $0.1 \%$.

\subsubsection{Precipitated compounds identification}

The precipitated solids obtained in the crystalliser were extracted from the reaction zone and were air dried at room temperature. Then, X-Ray Powder Diffraction (XRD) was applied in order to check whether struvite crystals were formed. The equipment used for X-ray analyses was a D8 Avance A25 powder diffractometer (Bruker, Karlsruhe, Germany). About $0.01 \mathrm{~g}$ of sample were placed in a sample holder and then into the X-ray chamber at $1200^{\circ} \mathrm{C}$. A scanning step of $0.02^{\circ}$ and a pass of $0.02 \mathrm{~s}$ were fixed as working constants.

Moreover, the composition of the the precipitated solids was analysed by energydispersive X-ray spectroscopy (EDS) by searching the presence of the following elements: P, N, Mg, Ca and K. This EDS microanalysis was carried out by means of a XL-30 ESEM (Philips, Eindhoven, Netherlands). Struvite samples were attached to the Scanning Electron Microscopy (SEM) stub using silver lacquer. Then, the SEM stub with the sample was introduced into the XL-30 and the pressure was diminished until $10^{-5}$ bar. After that, the sample surface was visualised and an area was selected for the microanalysis. The spot-size value was modified until a Dead Time (DT) around $30 \%$ was achieved.

\subsubsection{Total organic carbon}

Total Organic Carbon (TOC) was determined using the Elemental Analyser EA 1110 CHNS (CE Instruments Ltd, Wigan, United Kingdom). An amount of $0.1 \mathrm{~g}$ of sample was placed in a lightweight tin capsule. Then $250 \mu \mathrm{L}$ of $\mathrm{HCl}(37 \% \mathrm{w} / \mathrm{v})$ were added. The capsule was placed in an oven at $50^{\circ} \mathrm{C}$ in order to remove moisture. Then, the sample was placed in the auto-sampler and degasified in order to remove $\mathrm{N}_{2}$ and $\mathrm{CO}_{2}$. After that, the sample was preheated up to $1000^{\circ} \mathrm{C}$ by means of a constant stream of 
He. Later, the sample was enriched with a stream of oxygen and the temperature was increased up to $1800{ }^{\circ} \mathrm{C}$ by the Dynamic Flash Combustion protocol. Combustion products $\left(\mathrm{N}_{2}, \mathrm{CO}_{2}, \mathrm{H}_{2} \mathrm{O}\right.$ and $\left.\mathrm{SO}_{2}\right)$ were separated and detected by means of gas chromatography coupled to a Thermal Conductivity Detector (TCD).

\subsubsection{Organic micropollutants}

Those priority pollutants considered in Directive 2013/39/UE as substances that tend to accumulate in solid matrices, as well as other emerging micropollutants, were analysed. Solid Phase MicroExtraction (SPME) fibres (Supelco, Bellefonte, Pennsylvania, USA) were used as pre-concentration technique, followed by Gas Chromatography (6890 GC) coupled to Mass Spectrometry Detector (5973 inert MSD) or to Liquid Chromatography (LC) coupled to Fluorescent Detection (FD) (1100 Series) (Agilent Technologies, San José, USA). A volume of $5 \mathrm{~mL}$ of water were added to $0.1 \mathrm{~g}$ of sample in a $20 \mathrm{~mL}$ vial. Then $\mathrm{H}_{2} \mathrm{SO}_{4}$ was added until complete dissolution, and the rest of the volume was filled with water up to $20 \mathrm{~mL}$. After that, SPME was carried out and then, the sample was analysed by GC-MS or LC-FD.

\section{Results and Discussion}

This section presents a descriptive analysis of the main results obtained in the study conducted in Calahorra WWTP. First, the results from lab-scale experiments, which were used for the crystallisation demonstration plant design, are presented. Secondly, the main figures of the validation of the upgraded sludge line configuration are detailed. Finally, the section shows the technical and the economic performance of the P-recovery system proposed in the paper.

\subsection{Lab-scale crystallisation assays}

The lab-scale crystallisation reactor was fed with the thickener supernatant from Calahorra WWTP meanwhile the upgraded sludge line configuration was ran in manual mode (i.e., no elutriation control algorithm was as yet implemented) at the operating conditions described in section 2.1.

Table 1 presents the main operating conditions and experimental results for the three experiments performed to evaluate the effect of the HRT in the reaction zone of the crystalliser. This parameter was used to fix the demonstration crystalliser dimensions once the thickener supernatant flow rate was chosen as the stream to be treated. Experiments 1, 2 and 3 were ran for 52, 30 and 25 days, respectively. Magnesium, ammonium, phosphate and total phosphorus were analysed on a daily basis from Monday to Friday. pH was measured on-line. Struvite samples were collected once a week for solids characterisation.

Two types of efficiencies were calculated to evaluate the $\mathrm{P}$ crystallisation process: Precipitation Efficiency was calculated using the soluble phosphate concentration in the effluent and Recovery Efficiency was calculated by considering the total phosphate concentration in the effluent (soluble phosphate+fine particles driven out with the effluent). These efficiencies were calculated according to Pastor et al. (2008b). 
The precipitation efficiency showed values above $95 \%$ irrespective of the HRT studied. This led to quite low soluble P concentration in the crystalliser effluent. However, the recovery efficiency decreased when the HRT was diminished, giving rise to an increase in the total $\mathrm{P}$ in the crystalliser effluent. Differences between the two efficiencies can be explained due to the formation of fine crystals which are lost with the effluent and, consequently, are not recovered. These results indicated that more fine crystals, which showed worse settling characteristics, were formed when the HRT was lower. The increase in the total P measured in the crystalliser effluent clearly indicates that fine struvite particles were formed and not retained in the crystalliser. The $\mathrm{PO}_{4}-\mathrm{P}$ concentration kept almost constant irrespective of the HRT, showing that the precipitation process is not affected by the HRT increase. However, the total P increased when the HRT increased, indicating that a large number of fine struvite particles were formed at higher HRT. So, the decrease in HRT gave rise to a change in the hydraulics of the reactor causing the reduction of the crystal size, while the yield of the phosphorus precipitation rested invariable. This effect was also observed by Pastor et al. (2008a) treating a synthetic wastewater. Nevertheless, the particles formed in the reaction zone showed adequate average sizes above $180 \mu \mathrm{m}$ in the three experiments. The struvite production was around 1 gram per litre of thickener supernatant fed to the crystalliser.

Table 1. Crystallising process results for the three lab-scale experiments.

\begin{tabular}{lccc}
\hline & Exp. 1 & Exp. 2 & Exp. 3 \\
\hline HRT (h) & 4.35 & 2.05 & 1.05 \\
$\mathrm{pH}$ & $8.7 \pm 0.1$ & $8.7 \pm 0.1$ & $8.7 \pm 0.1$ \\
$\mathrm{Mg} / \mathrm{P}$ molar ratio & $1.5 \pm 0.3$ & $1.6 \pm 0.1$ & $1.6 \pm 0.1$ \\
$\mathrm{~N} / \mathrm{P}$ molar ratio & $2.3 \pm 0.2$ & $2.6 \pm 0.1$ & $2.4 \pm 0.2$ \\
$\mathrm{PO}_{4}-\mathrm{P}_{\text {influent }}(\mathrm{mg} / \mathrm{L})$ & $150 \pm 26$ & $134 \pm 6$ & $132 \pm 9$ \\
Total $_{\text {effluent }}(\mathrm{mg} / \mathrm{L})$ & $14 \pm 5$ & $24 \pm 2$ & $36 \pm 11$ \\
$\mathrm{PO}_{4}-\mathrm{P}_{\text {effluent }}(\mathrm{mg} / \mathrm{L})$ & $5.9 \pm 0.8$ & $4.7 \pm 0.5$ & $5.5 \pm 0.9$ \\
Precipitation Efficiency $(\%)$ & $95.8 \pm 1.3$ & $96.4 \pm 0.3$ & $95.8 \pm 0.9$ \\
Recovery Efficiency $(\%)$ & $89.7 \pm 5.9$ & $82.1 \pm 1.7$ & $72.0 \pm 10.0$ \\
Struvite production & $1.1 \pm 0.3$ & $1.0 \pm 0.1$ & $0.96 \pm 0.08$ \\
(g struvite/L supernatant treated) & & & \\
Average particle size $(\mu \mathrm{m})$ & $183 \pm 59$ & $207 \pm 8$ & $213 \pm 19$ \\
\hline
\end{tabular}

The results allowed the choice of the suitable HRT to obtain a high P recovery efficiency. The average particle size distribution under these operating conditions was between $183 \mu \mathrm{m}$ and $213 \mu \mathrm{m}$. The knowledge of this particle size distribution was essential to design the solid extraction device (bottom part of the reactor) and the settler (upper part of the reactor) in the crystallisation plant at demonstration-scale.

\subsection{P-recovery demonstration plant design}

According to the efficiency and particle size values obtained in the lab-scale experiments, the demonstration plant design was based on an HRT between $2 \mathrm{~h}$ and 4h. Scale-up criteria and Computational Fluid Dynamics (CFD) were used to design the reactor. The material chosen to build the reactor was High Density Polyethylene 
(HDPE) in order to reduce possible scaling of crystals on the walls that would reduce the recovery efficiency and induce problems in long term operation of the reactor.

The crystallisation reactor (ES $1156783 \mathrm{U}$ ) was designed for a maximum treatment flow of $20 \mathrm{~m}^{3} / \mathrm{d}$ and a minimum HRT of $2 \mathrm{~h}$. As for the lab-reactor, the reactor of 5.12 $\mathrm{m}^{3}$ in total volume was divided in a $2.11 \mathrm{~m}^{3}$ reaction zone and a $3.01 \mathrm{~m}^{3}$ sedimentation zone to keep the solid particles inside of the reactor (see Figure 3). Thus, the reactor operation was in continuous mode with the liquid phase and in batchwise with the solid particles. $\mathrm{MgCl}_{2} \cdot 6 \mathrm{H}_{2} \mathrm{O}$ solution was mixed with the gravity thickener supernatant in order to achieve the appropriate $\mathrm{Mg} / \mathrm{P}$ molar ratio to generate struvite, and $\mathrm{NaOH}$ solution was also added to maintain the $\mathrm{pH}$ in the desired value. A fuzzy-logic control algorithm for $\mathrm{pH}$ was developed based on Chanona et al. (2006) for an optimal operation of the struvite crystallisation process. The control system consisted in a feedback control of the measured $\mathrm{pH}$ in the crystalliser by manipulating the $\mathrm{NaOH}$ flow rate. This flow rate was modified by changing the pump stroking frequency.

\subsection{Validation of the upgraded sludge line configuration}

Once the P-recovery system was completely implemented in Calahorra, including the elutriation system controller, it has been assessed for a period of seven months (see Figure 4) (data from day 49 to 59 were excluded from the discussion since the sludge line was inoperative due to operational problems). During this validation period, only one of the two anaerobic digesters was fully operated in Calahorra WWTP. In addition, it is important to highlight that during the whole operating period the $\mathrm{P}$ removal efficiency in the water line showed high values between $80-92 \%$.

From day 0 to 93 , the elutriation system controller was calibrated and from day 94 onwards the elutriation system was automatically operated. As seen in Figure 4a, during this second period, the $\mathrm{PO}_{4}-\mathrm{P}$ concentration in the thickener effluent (stream to be fed to the crystalliser) varied between 45.7 and $144 \mathrm{mg} / \mathrm{L}$, showing an average concentration of $97.1 \mathrm{mg} / \mathrm{L}$; the sludge blanket level was kept below the set point $(1.5$ $\mathrm{m})$, almost all the time; and the elutriation flow rate ranged from 17 to $101 \mathrm{~m}^{3} / \mathrm{d}$ (average flow rate of $65 \mathrm{~m}^{3} / \mathrm{d}$ ). The fluctuations in the $\mathrm{PO}_{4}-\mathrm{P}$ concentration are not only attributed to the elutriation flow rate variations but also to the primary sludge flow rate values. As seen in Figure 4b, an increase in the primary sludge flow rate quickly decreases the $\mathrm{PO}_{4}-\mathrm{P}$ concentration in the thickener supernatant due to a dilution effect of the P-enriched elutriation stream. The primary sludge flow rate therefore should be maintained as low as possible in order to avoid a dilution of the $\mathrm{PO}_{4}-\mathrm{P}$ concentrations in the thickener supernatant stream.

From day 94 onwards, three intensive analytical campaigns of the sludge treatment line (sampling points indicated in Figure S1) were carried out in order to assess the success of the implemented configuration in reducing the uncontrolled $\mathrm{P}$ precipitation in the digester and increasing the available $\mathrm{P}$ in the supernatants obtained. The sampling campaigns were properly spaced to take into account the HRT in the anaerobic digester (20 days).

Table S1 presents the results obtained (average and standard deviation) in the three analytical campaigns carried out in the sludge line. As can be observed, the elutriation system was able to increase the $\mathrm{PO}_{4}-\mathrm{P}$ concentration in the thickener supernatant (SP 
5) reaching an average value of $96.4 \pm 14.3 \mathrm{mg} / \mathrm{L}$, which means approximately 2.6 times more than the $\mathrm{PO}_{4}-\mathrm{P}$ concentration achieved with the previous conventional operation (37.8 $\pm 13.3 \mathrm{mg} / \mathrm{L}$ ) (Martí et al., 2017). This can be explained by the mixing of the thickened primary sludge, which contains a high volatile acid concentration (VFA) of about $700 \mathrm{mg} / \mathrm{L}$, and the secondary sludge from the EBPR process rich in Poly-P, which is released under anaerobic conditions in the mixing chamber. Then, the mixed sludge is recirculated to the thickener, in which phosphate will be washed and extracted with the thickener supernatant. The $\mathrm{PO}_{4}-\mathrm{P}$ concentration in the digested sludge centrate remains high, equal to $81.5 \pm 15.4 \mathrm{mg} / \mathrm{L}$. Indeed, this concentration is quite similar to the one obtained during the conventional operation $(84.6 \pm 32.5 \mathrm{mg} / \mathrm{L})$ indicating that the elutriation system does not decrease the $\mathrm{P}$ availability in the centrate, increasing thus the total $\mathrm{P}$ available for its recovery.

From the analytical results obtained, mass balances were applied in the different units of the sludge treatment line (mixing chamber, anaerobic digester, secondary digester and sludge dewatering) following a previously developed methodology (Martí et al., 2008). Table 2 compares the results obtained under the upgraded sludge configuration (with elutriation) with the ones obtained under the previous conventional operation (without elutriation). In order to compare both operating periods, the results are calculated in each period on a treated sludge mass flow rate basis (i.e., $4057 \mathrm{~kg}$ TS/d and $3136 \mathrm{~kg}$ TS/d, in the conventional and upgraded configurations, respectively).

Table 2 Potential P-recovery assessment: conventional and upgraded configuration of the sludge treatment line.

\begin{tabular}{lcc}
\hline & $\begin{array}{c}\text { Conventional } \\
\text { configuration } \\
\text { (Without elutriation) }\end{array}$ & $\begin{array}{c}\text { Upgraded } \\
\text { configuration } \\
\text { (With elutriation) }\end{array}$ \\
\hline P lost (gP/kg sludge): & & \\
Precipitation in anaerobic digester & 9.52 & 5.46 \\
Precipitation in the mixing chamber & 3.82 & 4.56 \\
Precipitation in secondary digester & 0.26 & 0.34 \\
Dewatered sludge & 0.25 & 0.37 \\
Total P lost & 13.85 & 10.73 \\
\hline P available (gP/kg sludge): & & 1.88 \\
Primary thickener supernatant & 0.39 & 0.22 \\
Secondary thickener supernatant & 0.13 & 2.41 \\
Dewatering centrate & 1.67 & 4.51 \\
Total P available & 2.19 & $\mathbf{2 9 . 6}$ \\
\hline Potential P-recovery (\%) & $\mathbf{1 3 . 7}$ & \\
\hline
\end{tabular}

Table 2 presents that the proposed sludge treatment operation leads to a significant reduction of the uncontrolled $\mathrm{P}$ precipitation in the digester from 9.52 to $5.46 \mathrm{gP} / \mathrm{kg}$ sludge. This can be attributed to a reduction of the $\mathrm{P}$ load to the anaerobic digester by enhancing its release in the mixing chamber and further separation by elutriation. As Table 2 points out, $\mathrm{P}$ precipitation also occurred in the mixing chamber despite the low $\mathrm{pH}$ that was achieved (i.e., 6.3 and 6.8, in the conventional and upgraded configurations, respectively). The precipitation in the mixing chamber can be mainly attributed to the high $\mathrm{P}$ concentration reached because of Poly-P hydrolysis. Other 
insignificant $\mathrm{P}$ losses were observed by precipitation in the secondary digester and in the dewatering system, since some part of phosphate remains in the dewatered sludge.

On the other hand, two supernatant streams contain high amounts of available $\mathrm{P}$ that could be recovered as struvite in a crystallisation process: the primary thickener supernatant and the centrifuge centrate. Table 2 presents that the Potential P-recovery $(\%)$, (i.e., the phosphorus that could be recovered in a crystallisation process with regard to the maximum phosphorus available in the sludge treatment system) increases from 13.7 to $29.6 \%$. Regarding the total P entering the WWTP, this result means that $19 \%$ of the total $\mathrm{P}$ could be recovered with the upgraded configuration proposed in comparison with $9 \%$ in the previous conventional configuration (Martí et al., 2017). Indeed, $P$ availability increases to a greater extend in the primary thickener supernatant due to the elutriation system. The $\mathrm{P}$ available in the primary thickener supernatant was nearly five times more than the obtained for the conventional configuration (1.88 vs. $0.39 \mathrm{gP} / \mathrm{kg}$ sludge). In addition, $\mathrm{P}$ availability in the digested sludge centrate was even slightly higher when the plant was operated with the elutriation loop. These results confirmed that the upgraded sludge line configuration was able to reduce the uncontrolled $\mathrm{P}$ precipitation in the digester and to increase the $\mathrm{P}$ availability for its recovery in a crystallisation reactor.

\subsection{Implementation of the P-recovery demonstration plant and} characterisation of the struvite obtained

The P-recovery demonstration plant was operated from day 94 onwards, once the elutriation system was automatically operated. Based on the lab-scale crystallisation results, the HRT in the reaction zone was set around 4 hours, treating $11.9 \mathrm{~m}^{3} / \mathrm{d}$, equivalent to $19 \%$ of the thickener supernatant flow rate. Table 3 presents the main characteristics of the crystalliser operating conditions.

The molar ratios $\mathrm{Mg} / \mathrm{P}, \mathrm{N} / \mathrm{P}, \mathrm{Ca} / \mathrm{P}$ and $\mathrm{Ca} / \mathrm{Mg}$ have an important influence on the precipitation and recovery efficiencies of the crystallisation process and must be considered (Peng et al., 2018). Precipitation and recovery efficiencies improve at high $\mathrm{Mg} / \mathrm{P}$ and N/P ratios (Pastor et al., 2008a). According to the literature (Musvoto et al., 2000), struvite precipitates at neutral and higher $\mathrm{pH}$ and at $\mathrm{Mg} / \mathrm{Ca}$ molar ratios higher than 0.6. The influence of calcium on struvite crystallization was experimentally studied by several authors (Le Corre et al., 2005; Wang et al., 2005; Pastor et al., $2008 \mathrm{~b}$ ). Le Corre et al. (2005) indicated that $\mathrm{Ca} / \mathrm{Mg}$ molar ratio of 0.5 inhibited struvite growth, generating amorphous calcium phosphate precipitated on struvite surface; and $\mathrm{Ca} / \mathrm{Mg}$ molar ratio above 1 gave rise to the formation of an amorphous precipitate rather than crystalline struvite. Pastor et al., (2008b) observed a lower struvite formation at $\mathrm{Ca} / \mathrm{Mg}$ molar ratio of 1.6. Ye et al. (2016) observed a significant increase in removal capacity using a $\mathrm{Mg} / \mathrm{P}$ molar ratio of more than 1.8. In this work, magnesium was added to increase the molar ratio $\mathrm{Mg} / \mathrm{P}$ from 0.6 until 1.6 , satisfying the stoichiometric demand for struvite formation and reducing the influent $\mathrm{Ca} / \mathrm{Mg}$ molar ratio from 2.6 to 0.9 . In the case of the $\mathrm{N} / \mathrm{P}$ molar ratio, $\mathrm{NH}_{4}-\mathrm{N}$ concentrations in the influent crystalliser stream were slightly higher than $\mathrm{PO}_{4}-\mathrm{P}$ concentrations giving rise to a quite high $\mathrm{N} / \mathrm{P}$ molar ratio, indicating that $\mathrm{NH}_{4}-\mathrm{N}$ will not limit the struvite formation.

The average phosphorus precipitation efficiency in the crystallisation plant was $92.8 \pm 0.5 \%$ yielding a struvite production of $8.5 \pm 0.7 \mathrm{~kg} / \mathrm{d}\left(0.72 \pm 0.05 \mathrm{~kg} / \mathrm{m}^{3}\right.$ of 
supernatant fed to the crystalliser). Regarding that the average recovery efficiency was $86.9 \pm 0.4 \%$, the struvite recovered in the pilot plant was $8.0 \pm 0.6 \mathrm{~kg} / \mathrm{d}(0.67 \pm 0.04$ $\mathrm{kg} / \mathrm{m}^{3}$ of supernatant fed to the crystalliser). Thus, if all the thickener supernatant flow rate of the WWTP was treated in the crystallisation process, the potential struvite production from the thickener supernatant in the WWTP would be around $41 \mathrm{~kg} / \mathrm{d}(15$ $\mathrm{t} / \mathrm{y}$ ). Moreover, considering the fact that the centrate stream from the digested sludge has similar $\mathrm{PO}_{4}-\mathrm{P}$ concentrations (Table $\mathrm{S} 1$ ), the total struvite production in the WWTP treating all the P-enriched streams could be estimated around $103 \mathrm{~kg} / \mathrm{d}$ (38 t/y), assuming a similar precipitation efficiency.

Table 3 Crystallisation plant operating conditions

\begin{tabular}{ccrl}
\hline \multicolumn{3}{c}{ Influent composition } \\
\hline $\mathrm{PO}_{4}-\mathrm{P}$ & $(\mathrm{mg} / \mathrm{L})$ & 96 & \pm 14 \\
$\mathrm{NH}_{4}-\mathrm{N}$ & $(\mathrm{mg} / \mathrm{L})$ & 102 & \pm 9 \\
$\mathrm{Mg}^{2+}$ & $(\mathrm{mg} / \mathrm{L})$ & 46 & \pm 12 \\
$\mathrm{Ca}^{2+}$ & $(\mathrm{mg} / \mathrm{L})$ & $202 \pm 24$ \\
$\mathrm{~K}^{+}$ & $(\mathrm{mg} / \mathrm{L})$ & $83 \pm 23$ \\
$\mathrm{P}_{\mathbf{T}}$ & $(\mathrm{mg} / \mathrm{L})$ & $122 \pm 22$ \\
$\mathrm{pH}$ & & $6.41 \pm 0.16$ \\
$\mathrm{Ca} / \mathrm{P}$ & $\mathrm{mol} / \mathrm{mol}$ & $1.6 \pm 0.3$ \\
$\mathrm{Mg} / \mathrm{P}$ & $\mathrm{mol} / \mathrm{mol}$ & $0.6 \pm 0.1$ \\
$\mathrm{~N} / \mathrm{P}$ & $\mathrm{mol} / \mathrm{mol}$ & $2.3 \pm 0.3$ \\
\hline \multicolumn{4}{c}{ Operating parameters } \\
$\mathrm{Q}$ & $\left(\mathrm{m}^{3} / \mathrm{d}\right)$ & $11.9 \pm 0.2$ \\
$\mathrm{HRT}_{\text {reaction zone }}$ & $\mathrm{h}$ & $4.1 \pm 0.2$ \\
$\mathrm{Mg} / \mathrm{P}$ & $\mathrm{mol} / \mathrm{mol}$ & $1.6 \pm 0.2$ \\
$\mathrm{pH}$ & & $8.70 \pm 0.21$ \\
\hline
\end{tabular}

To determine the main characteristics of the crystals produced, 10 samples were grabbed from the purge zone of the crystallisation plant during the operation period. In these samples, crystal type and size, TOC, P, Mg and Ca content, heavy metals concentration and organic micropollutants concentration were determined.

X-ray diffraction analysis of the solids produced showed that struvite was formed (Figure S2 (a)). The EDS analysis indicated that the particles obtained in the reactor were mainly struvite (particles composition: $12.4 \pm 0.3 \% \mathrm{P}, 9.5 \pm 0.1 \% \mathrm{Mg}, 5.8 \pm 0.3 \%$ $\mathrm{N}, 5.7 \pm 0.7 \% \mathrm{Ca}$ and $0.35 \pm 0.07 \% \mathrm{~K})$. No potassium struvite $\left(\mathrm{KMgPO}_{4} \cdot 6 \mathrm{H}_{2} \mathrm{O}\right)$ was formed in the crystalliser because of the high $\mathrm{NH}_{4}-\mathrm{N}$ concentrations which hinder its formation (Schuiling and Andrade, 1999; Wilsenach et al., 2006). However, the results also indicated a high percentage of $\mathrm{Ca}$ due to the high $\mathrm{Ca}$ concentration in the stream fed to the crystalliser. Thus, the solids could also contain some amorphous calcium phosphate. Elemental analysis assays also pointed out that TOC in the struvite ranged from 0.6 to $0.8 \%$ (of dry weight).

The average particle size was another important parameter to evaluate the recovery efficiency of phosphorus by the process of struvite crystallisation as well as its handling at the time of its distribution. Figure S2 (b) presents the size distribution of a solid sample taken from the reaction zone of the crystalliser. A maximum can be clearly observed around $700 \mu \mathrm{m}$. Besides, a small peak around $100 \mu \mathrm{m}$ can be also 
observed, which presumably corresponds to organic and inorganic matter contamination entering the crystalliser with the feed stream. Two parameters were assessed to determine the struvite particle size: D[4,3], which supposes that particles are spheres, and the Percentile 50 (Diameter 50\%), which indicates the diameter value below which $50 \%$ of the sample volume is found. The particles extracted from the purge zone of the crystalliser showed a $\mathrm{D}[4,3]$ value of $723 \pm 12 \mu \mathrm{m}$ and a Percentile 50 of $681 \pm 13 \mu \mathrm{m}$. The particles formed showed therefore adequate average sizes $(>200 \mu \mathrm{m})$ for the obtainment of a marketable product.

Table 4 compares the heavy metals concentrations found in digested sludge from three urban WWTPs with the ones obtained in the struvite produced at Calahorra WWTP. Moreover, Table 4 presents the maximum heavy metals concentrations allowed in waste sludge for agrarian purposes in Spain (BOE, 1990) and the struvite requirements regarding metals content proposed by the European Sustainable Phosphorus Platform (ESPP) (ESPP, 2015) and the European Commission (EC, 2016) to integrate struvite into the EU Fertiliser Regulation.

The results clearly show that the retention of the analysed metals is significantly higher in the sludge than in the struvite samples. As can be observed, $\mathrm{Zn}$ was the only metal detected in struvite samples. The struvite metal concentrations are much lower than the limits established by the Spanish Regulation (BOE, 1990) and also lower than the values proposed by the ESPP and the European Commission. The low levels $(<3 \mathrm{mg} / \mathrm{kg}$ ) of Cd (a common pollutant in P-based fertilisers from ground rock phosphate) is worth noting, taking into account that the average $\mathrm{Cd}$ content in fertilisers marketed in EU is around $45 \mathrm{mg} \mathrm{Cd} / \mathrm{kg} \mathrm{P}_{2} \mathrm{O}_{5}$ (ESPP, 2013).

Table 4. Heavy metal concentrations in the crystals obtained $\left(\mathrm{mg} / \mathrm{kg}\right.$ dry matter; $\left.* \mathrm{mg} / \mathrm{kg} \mathrm{P}_{2} \mathrm{O}_{5}\right)$. n: number of samples. n.a.: not available.

\begin{tabular}{|c|c|c|c|c|c|c|}
\hline Element & $\begin{array}{l}\text { RD } \\
\text { 1310/1990 } \\
\text { Annex I B } \\
\text { (Spanish } \\
\text { Regulation) }\end{array}$ & $\begin{array}{l}\text { Sludge } \\
\text { from } \\
\text { WWTP } 1 \\
(n=3)\end{array}$ & $\begin{array}{l}\text { Sludge } \\
\text { from } \\
\text { WWTP } 2 \\
(n=3)\end{array}$ & $\begin{array}{l}\text { Sludge } \\
\text { from } \\
\text { Calahorra } \\
\text { WWTP } \\
(n=5)\end{array}$ & $\begin{array}{l}\text { Proposed } \\
\text { struvite } \\
\text { requirements } \\
\text { (ESPP and } \\
\text { European } \\
\text { Comission) }\end{array}$ & $\begin{array}{l}\text { Struvite } \\
\text { from } \\
\text { Calahorra } \\
(n=10)\end{array}$ \\
\hline$\overline{\mathrm{Zn}}$ & 2500 & $1677 \pm 401$ & $1110 \pm 291$ & 1022 & n.a. & $118 \pm 60$ \\
\hline $\mathrm{Cd}$ & 20 & $2.2 \pm 0.5$ & $2.9 \pm 0.4$ & $1.0 \pm 0.3$ & $60 *$ & $<3$ \\
\hline $\mathrm{Cr}$ & 1000 & $116 \pm 38$ & $170 \pm 20$ & $68 \pm 12$ & 2 & $<2$ \\
\hline $\mathrm{Cu}$ & 1000 & $288 \pm 21$ & $318 \pm 38$ & $313 \pm 55$ & n.a. & $<2$ \\
\hline $\mathrm{Ni}$ & 300 & $67 \pm 6$ & $59 \pm 4$ & $40 \pm 2$ & 120 & $<3$ \\
\hline $\mathrm{Pb}$ & 750 & $52 \pm 15$ & $72 \pm 10$ & $48 \pm 9$ & 150 & $<6$ \\
\hline
\end{tabular}

Finally, the European Commission is drawing special attention on priority and emerging pollutants over the last years. Thus, another important aspect to be evaluated is the possible presence of priority and emerging pollutants in the obtained struvite. 81 compounds (Table S2) were analysed in the struvite samples grabbed from the purge zone of the crystallisation plant operation.

The analysis carried out indicated the presence at very low concentrations of only 9 out of 81 substances: Naphthalene $(32.7 \pm 6.8 \mu \mathrm{g} / \mathrm{kg})$, Fluoranthene $(3.8 \pm 1.2 \mu \mathrm{g} / \mathrm{kg})$, Benz[a]anthracene $(1.5 \pm 0.7 \mu \mathrm{g} / \mathrm{kg})$, Chrysene $(4.8 \pm 3.8 \mu \mathrm{g} / \mathrm{kg})$, Benzo[b]fluoranthene $(3.2 \pm 1.3 \mu \mathrm{g} / \mathrm{kg})$, Benzo[k]fluoranthene $(1.8 \pm 0.5 \mu \mathrm{g} / \mathrm{kg})$, Benzo[a]pyrene 
$(2.5 \pm 0.5 \mu \mathrm{g} / \mathrm{kg})$, Dibenz[a,h]anthracene $(1.0 \pm 0.7 \mu \mathrm{g} / \mathrm{kg})$ and Benzo[g,h,i]perylene $(0.8 \pm 0.2 \mu \mathrm{g} / \mathrm{kg})$.

These values are quite lower than the ones usually found in the sludge produced in WWTPs (Abargues et al., 2012) and, in the case of Polycyclic Aromatic Hydrocarbons (PAHs), also below the proposed struvite requirements by ESPP (ESPP, 2015) and European Commission (i.e., PAHs: $6 \mathrm{mg} / \mathrm{kg}$ dry matter) (EC, 2016).

Overall, the struvite characteristics would fulfil the requirements for its use as fertiliser considering the guidelines launched by the ESPP and the European Commission. Nevertheless, further research on agriculture application assays is needed to test the fertilising effects of the struvite produced in the crystallisation reactor.

\subsection{Economic assessment}

An economic analysis is needed to ensure the feasibility of this technology to recover and recycle $\mathrm{P}$ from municipal wastewaters. Therefore, the production cost and market price of struvite must be considered. In this work, the implementation of a global Precovery system entails some operating costs and savings or profits: the costs have been mainly identified with chemical dosage for struvite crystallisation and the savings with the decrease in sludge production and chemical dosage in sludge dewatering. Moreover, struvite selling has also been considered as a profit fixing a market price for this compound. Table 5 summarises the main costs and savings calculated during the P-recovery demonstration plant operation. As Table 5 shows, the main cost is related to the sodium hydroxide addition to maintain the $\mathrm{pH}$ in the crystalliser. Regarding the incomes, the dewatered sludge reduction is worth noting. The implementation of the $\mathrm{P}$ recovery system (elutriation+crystallisation) gave rise to a decrease in the sludge produced in the WWTP of $118 \mathrm{~kg}(d . w) / \mathrm{d}$ on average. The reduction in the sludge generation also implies a lower polyelectrolyte consumption (i.e., a reduction of $2.33 \mathrm{~kg} / \mathrm{d}$ in chemical dosage) in the dewatering system, which represents an important saving.

Table 5. Summary of economic analysis during the struvite crystallisation operation period.

\begin{tabular}{lllll}
\hline Product & $\begin{array}{l}\text { Amount } \\
(\mathbf{k g} / \mathbf{d})\end{array}$ & $\begin{array}{l}\text { Price } \\
(\boldsymbol{€} / \text { /ton })\end{array}$ & $\begin{array}{l}\text { Cost/Income } \\
(\boldsymbol{€} / \mathbf{d})\end{array}$ & $\begin{array}{l}\text { Cost/Income } \\
(\boldsymbol{€} / \mathbf{k g ~ P})\end{array}$ \\
\hline Costs & & & & \\
\hline $\mathrm{MgCl}_{2} \cdot 6 \mathrm{H}_{2} \mathrm{O}$ & 8.05 & 370 & 2.98 & 2.95 \\
$\mathrm{NaOH}$ & 7.25 & 620 & 4.49 & 4.45 \\
\hline Profits\&Savings & & & & \\
\hline MgNH$_{4} \mathrm{PO}_{4} \cdot 6 \mathrm{H}_{2} \mathrm{O}$ & 8.00 & 302 & 2.42 & 2.39 \\
Dewatered Sludge not produced & 118 & 37.1 & 4.38 & 4.34 \\
Polyelectrolyte not consumed & 2.33 & 2340 & 5.46 & 5.41 \\
\hline
\end{tabular}

The prices for the chemicals and the sludge withdrawal were obtained from the WWTP operators. In the case of struvite price, the estimations made by different authors point out that the market value is between 188 and $763 € /$ ton (Molinos et al., 2011). In this study, the struvite price has been calculated by multiplying the nutrient 
concentration in the product by their common market value $(\mathrm{P}: 1.7 € / \mathrm{kg}, \mathrm{N}: 1.1 € / \mathrm{kg}$, $\mathrm{Mg}: 0.3 € / \mathrm{kg}$, and Ca: $0.1 € / \mathrm{kg}$ ) (Egle et al., 2016) giving a value of $302 € / \mathrm{ton}$. Then, the main operating costs associated to the $\mathrm{P}$ crystallisation represents $7.40 € / \mathrm{kg}$ of $\mathrm{P}$ recovered and the savings $12.14 € / \mathrm{kg}$ of $\mathrm{P}$ recovered. Therefore, the revenue would be around $4.74 € / \mathrm{kg}$ of $\mathrm{P}$ recovered indicating a potential feasibility of the implemented system. Nevertheless, a full economic analysis considering other inputs and outputs of the process (i.e., energy consumption in pumping and mixing in the elutriation and crystallisation systems, savings in maintenance due to uncontrolled precipitation minimisation, etc...) should be necessary. Moreover, in addition to the economic benefits, the environmental benefits (i.e., eutrophication prevention and an increase in the availability of a non-renewable resource) should be also considered in a more detailed feasibility analysis.

\section{Conclusions}

$\mathrm{P}$ extraction before anaerobic digestion produced an average $\mathrm{PO}_{4}-\mathrm{P}$ concentration in the thickener supernatant (stream to be fed to the crystalliser) of $97.1 \mathrm{mg} / \mathrm{L}$ working at elutriation flow rates between 17 to $101 \mathrm{~m}^{3} / \mathrm{d}$. Both elutriation as well as primary sludge flow rates are the key to maximise the $\mathrm{P}$ recovery in the proposed elutriation system. Primary sludge flow rate should be maintained as low as possible to keep $\mathrm{PO}_{4}-\mathrm{P}$ concentrations in the thickener supernatant in high values.

The elutriation system increased the $\mathrm{P}$ availability in the primary sludge overflow nearly five times more than with the former configuration $(1.88 \mathrm{vs} .0 .39 \mathrm{gP} / \mathrm{kg}$ sludge treated). The global P-recovery system implemented allows the recovery of $19 \%$ of the total $\mathrm{P}$ entering the WWTP. Moreover, the elutriation reduced $\mathrm{P}$ precipitation in the digester from 9.52 to $5.46 \mathrm{gP} / \mathrm{kg}$ sludge treated. Despite the important decrease in uncontrolled precipitation, a considerable amount of $\mathrm{P}$ is still lost due to organic $\mathrm{P}$ release and subsequent precipitation in the anaerobic digester.

A $5.12 \mathrm{~m}^{3}$ crystallisation plant has been designed and operated for treating thickener supernatant showing an average phosphorus precipitation efficiency of $92.8 \pm 0.5 \%$ and yielding a struvite production of $8.5 \pm 0.7 \mathrm{~kg} / \mathrm{d}\left(0.72 \pm 0.05 \mathrm{~kg} / \mathrm{m}^{3}\right.$ of supernatant fed to the crystalliser). The average recovery efficiency was $86.9 \pm 0.4 \%$, therefore the struvite recovered in the pilot plant was $8.0 \pm 0.6 \mathrm{~kg} / \mathrm{d}\left(0.67 \pm 0.04 \mathrm{~kg} / \mathrm{m}^{3}\right.$ of supernatant fed to the crystalliser).

The potential struvite production from the thickener supernatant in the WWTP would be around $41 \mathrm{~kg} / \mathrm{d}(15 \mathrm{t} / \mathrm{y})$. The total struvite production in the WWTP treating both the thickener supernatant and the digested sludge centrate would be around $103 \mathrm{~kg} / \mathrm{d}$ (38 t/y). An economic assessment considering the main costs and profits of the Precovery system implemented reveals that the revenue would be around $4.74 € / \mathrm{kg}$ of $\mathrm{P}$ recovered.

The struvite obtained showed a high purity with low levels of metals, organic carbon and priority pollutants. So, its direct use as slow release fertiliser or as a raw material for other fertilisers manufacturing would be favoured, contributing to mitigate the phosphate reserves depletion. Moreover, the production and use of struvite has other environmental advantages: it reduces the risk of eutrophication of surface water bodies and the risk of contamination of aquifers as well as it reduces the sludge production and maintenance costs of the WWTP. 
Despite the implemented P recovery system seems to be technically and economically feasible further studies should be undertaken focused on: improving the economic balance of struvite crystallization testing other $\mathrm{Mg}$ sources such as seawater or any by-product from $\mathrm{MgO}$ production; enhancing the organic $\mathrm{P}$ release applying enzymatic or thermal pretreatments; and testing the fertilising effects of the struvite produced.

\section{ACKNOWLEDGEMENTS}

This work was co-financed by the European Financial Instrument for the Environment (LIFE +) as part of the PHORWater Project (LIFE12 ENV/ES/000441). The authors also like to acknowledge the support received from Consorcio de Aguas y Residuos de La Rioja and from EDAR del Cidacos (Calahorra).

\section{References}

Abargues, M.R., Robles, A., Bouzas, A., Seco, A., 2012. Micropollutants removal in an anaerobic membrane bioreactor and in an aerobic conventional treatment plant. Water Sci. Technol. 65 (12), 2242-50.

APHA, 2012. American Public Health Association/American Water Works Association/ Water Environmental Federation. Standard Methods for the Examination of Water and Wastewater, twenty-second ed. (Washington DC, USA).

Barat, R., Bouzas, A., Martí, N., Ferrer, J., Seco A., 2009. Precipitation assessment in wastewater treatment plants operated for biological nutrient removal: A case study in Murcia, Spain. Journal of Environ. Manag. 90, (2), 850-857.

Batstone, D. J., Hülsen, T., Mehta, C. M. \& Keller, J., 2015. Platforms for energy and nutrient recovery from domestic wastewater: a review. Chemosphere 140, 2-11.

Beuckels, A., Smolders, E., Muylaert., 2015. Nitrogen availability influences phosphorus removal in microalgae-based wastewater treatment. Water Res. 77, 98106.

BOE, Boletín Oficial del Estado no. 262 (1990) Real Decreto1310/1990, de 29 de octubre, por el que se regula la utilización de lodos de depuración en el sector agrario.

Chanona, J., Pastor, L., Borrás, L., Seco, A., 2006. Application of a fuzzy algorithm for $\mathrm{pH}$ control in a struvite crystallisation reactor. Water Sci. and Technol., 53, 161168.

Cieślik, B., Konieczka, P., 2017. A review of phosphorus recovery methods at various steps of wastewater treatment and sewage sludge management. The concept of "no solid waste generation" and analytical methods. J. Clean. Prod. 142, 1728-1740.

Cordell, D., Rosemarin, A., Schroder, J.J., Smit, A.L., 2011. Towards global phosphorus security: a systems framework for phosphorus recovery and reuse options. Chemosphere 84 (6), 747-758.

Desmidt, E., Ghyselbrecht, K., Zhang, Y., Pinoy, L., Van der Bruggen, B., Verstraete, W., Rabaey, K., Meesschaert, B., 2015. Global phosphorus scarcity and full-scale P recovery techniques: a review. Crit. Rev. Environ. Sci. Technol. 45, 336-384. 
EC, 2016. COM (2016) 157 final. Proposal for a regulation of the European Parliament and of the Council laying down rules on the making available on the market of CE marked fertilising products and amending Regulations (EC) No 1069/2009 and (EC) No 1107/2009.

EC, 2017. COM/2017/0490 final. Communication from the Commission to the European Parliament, the Council, the European Economic and Social Committee and the Committee of the Regions on the 2017 list of Critical Raw Materials for the EU.

Egle, L., Rechberger, H. Krampe, J., Zessner, M., 2016. Phosphorus recovery from municipal wastewater: An integrated comparative technological, environmental and economic assessment of P recovery technologies, Sci. Total Environ. 571, 522-542

ESPP, European Sustainable Phosphorus Platform, 2013. SCOPE Newsletter No 98, October 2013, https://www.phosphorusplatform.eu/2013

ESPP, European Sustainable Phosphorus Platform, 2015. Proposed EU Fertiliser Regulation criteria for recovered struvite.

http://phosphorusplatform.eu/images/download/ESPP\%20struvite\%20FR\%20criteria \%20proposal\%20sent\%2024-4-15.pdf

Huang, H., Zhang, D., Guom, G., Jiang, Y., Wang, M., Zhang, P., Li, J., 2018. Dolomite application for the removal of nutrients from synthetic swine wastewater by a novel combined electrochemical process. Chem. Eng. J. 335, 665-675.

Kataki, S., West, H., Clarke, M., Baruah, D.C., 2016a. Phosphorus recovery as struvite: Recent concerns for use of seed, alternative $\mathrm{Mg}$ source, nitrogen conservation and fertilizer potential. Resources, Conservation and Recycling 107, 142-156

Kataki, S., West, H., Clarke, M., Baruah, D.C., 2016b. Phosphorus recovery as struvite from farm, municipal and industrial waste: Feedstock suitability, methods and pre-treatments. Waste Manag. 49, 437-454.

Lahav, O., Telzhensky, M., Zewuhn, A., Gendel, Y., Gerth, J., Calmano, W. Birnhack, L., 2013. Struvite recovery from municipal-wastewater sludge centrifuge supernatant using seawater NF concentrate as a cheap $\mathrm{Mg}$ (II) source. Sep. and Purif. Technol. 108, 103-110.

Le Corre, K.S., Valsami-Jones, E., Hobbs, P., Parsons, S.A., 2005. Impact of calcium on struvite crystal size, shape and purity. J. Cryst. Growth 283 (3-4), 514-522.

Li, B., Boiarkina, I., Yu, W., Huang, H.M., Munir, T., Wang, G.Q., Young., B, 2019. Phosphorous recovery through struvite crystallization: Challenges for future design. Sci. Total Environ. 648, 1244-1256.

Martí, N., Barat, R., Seco, A., Pastor, L., Bouzas, A., 2017. Sludge management modeling to enhance P-recovery as struvite in wastewater treatment plants. J. Environ. Manag. 196, 340-346

Martí, N., Bouzas, A., Seco, A., Ferrer, J., 2008. Struvite precipitation assessment in anaerobic digestion processes. Chem. Eng. J. 141, 67-74.

Martí, N., Pastor, L., Bouzas, A., Ferrer, J., Seco, A., 2010. Phosphorus recovery by struvite crystallisation in WWTPs: Influence of the sludge treatment line operation. Water Res. 44 (7), 2371-2379. 
Mehta, C.M., Khunjar,W.O., Nguyen, V., Tait, S., Batstone, D.J., 2015. Technologies to recover nutrients from waste streams: a critical review. Crit. Rev. Environ. Sci. Technol. 45 (4), 385-427.

Molinos, M., Hernández, F., Sala, R., Garrido, M., 2011. Economic feasibility study for phosphorus recovery processes. AMBIO 40, 408-416.

Moosbrugger, R.E.,Wentzel, M.C., Ekama, G.A., Marais, G.V.R., 1992. Simple Titration Procedure to Determine H2CO3 Alkalinity and Short Chain Fatty Acids in Aqueous Solutions Containing Known Concentrations of Ammonium, Phosphate and Sulphide Weak Acid/Bases. WRC Report W74.

Musvoto, E.V., Wentzel, M.C., Ekama, G.A., 2000. Integrated chemical-physical processes modelling-II. Simulating aeration treatment of anaerobic digester supernatants. Water Res. 34, 1868-1880.

Parsons, S.A., Doyle, J.D., 2004. Struvite scale formation and control. Water Sci. Technol. 49 (2), 177-182.

Pastor, L., Mangin, D., Barat, R., Seco, A., 2008a. A pilot-scale study of struvite precipitation in a stirred tank reactor: Conditions influencing the process. Bioresour. Technol. 99 (14), 6285-6291.

Pastor, L., Mangin, D., Ferrer, J., Seco, A., 2010. Struvite formation from the supernatants of an anaerobic digestion pilot plant. Bioresour. Technol, 101 (1), 118125.

Pastor, L., Martí, N., Bouzas, A., Seco, A., 2008b. Sewage sludge management for phosphorus recovery as struvite in EBPR wastewater treatment plants. Bioresour. Technol. 99, 4817-4824.

Pearce, B. J., 2015. Phosphorus Recovery Transition Tool (PRTT): a transdisciplinary framework for implementing a regenerative urban phosphorus cycle. J. Clean. Prod., 109, 203-215.

Peng, L., Dai, H., Wu, Y., Peng, Y., Lu, X., 2018. A comprehensive review of phosphorus recovery from wastewater by crystallization processes. Chemosphere 197, 768-781.

Puyol, D., Batstone, D. J., Hülsen, T., Astals, S., Peces, M. \& Krömer, J. O., 2017. Resource recovery from wastewater by biological technologies: opportunities, challenges, and prospects. Frontiers in Microbiology 7 (2106), 1-23.

Seco, A., Aparicio, J. González-Camejo, A. Jiménez-Benítez, O. Mateo, J. F. Mora, G. Noriega-Hevia, P. Sanchis-Perucho, R. Serna-García, N. Zamorano-López, J. B. Giménez, A. Ruiz-Martínez, D. Aguado, R. Barat, L. Borrás, A. Bouzas, N. Martí, M. Pachés, J. Ribes, A. Robles, M. V. Ruano, J. Serralta and J. Ferrer., 2018. Resource recovery from sulphate-rich sewage through an innovative anaerobic-based water resource recovery facility (WRRF). Wat.Sci. \& Technol. 78 (9), 1925-1936.

Schuiling, R.D., Andrade, A., 1999. Recovery of struvite from calf manure. Environ. Technol. 20 (7), 765-768.

Tan, Z., Lagerkvist, A., 2011. Phosphorus recovery from the biomass ash: a review. Renew. Sustain. Energy Rev. 15 (8), 3588-3602.

Tao, X., Xia, H., 2007. Releasing characteristics of phosphorus and other substances during thermal treatment of excess sludge. J. Environ. Sci. 19 (10), 1153-1158. 
Tao,W., Fattah, K., Huchzermeier, M., 2016. Struvite recovery from anaerobically digested dairy manure: a review of application potential and hindrances. J. Environ. Manag. 169, 46-57.

Tarayre, C., De Clercq, L., Charlier, R., Michels, E., Meers, E., Camargo-Valero, M., Delvigne, F., 2016. New perspectives for the design of sustainable bioprocesses for phosphorus recovery from waste. Bioresour. Technol. 206, 264-274.

Wang, J., Burken, J.G., Zhang, X., Surampalli, R., 2005. Engineered struvite precipitation: impacts of component-ion molar ratios. J. Environ. Eng. 131 (10), $1433-1440$.

Wilsenach, J., Schuurbiers, C.A.H., van Loosdrecht, M.C.M., 2006. Phosphate and potassium recovery from source separated urine through struvite precipitation. Water Res. 41, 458-466.

Ye, Y., Ngo, H.H., Guo, W., Liu, Y., Li, J., Liu, Y., Zhang, X., Jia, H., 2017. Insight into chemical phosphate recovery from municipal wastewater. Sci Total Environ. 576, 159-171.

Ye, X., Ye, Z.L., Lou, Y., Pan, S.,Wang, X.,Wang, M.K., Chen, S., 2016. A comprehensive understanding of saturation index and upflow velocity in a pilot-scale fluidized bed reactor for struvite recovery from swine wastewater. Powder Technol. 295, 16-26.

Zhou, K., Barjenbruch, M., Kabbe, C., Inial, G., Remy, C., 2017. Phosphorus recovery from municipal and fertilizer wastewater: China's potential and perspective. J. Environ. Sci. 52, 151-159. 
Figure 1 General layout of the WWTP upgrade to a P-recovery system

Figure 2. Control strategy for the upgraded sludge line configuration.

Figure 3. General view (a) and flow diagram (b) of the demonstration crystallisation plant.

Figure 4. Performance of the elutriation system implemented. (a) $\mathrm{PO}_{4}-\mathrm{P}$, elutriation flow and sludge blanket height evolution. (b) $\mathrm{PO}_{4}-\mathrm{P}$, elutriation flow and primary sludge purge evolution. 


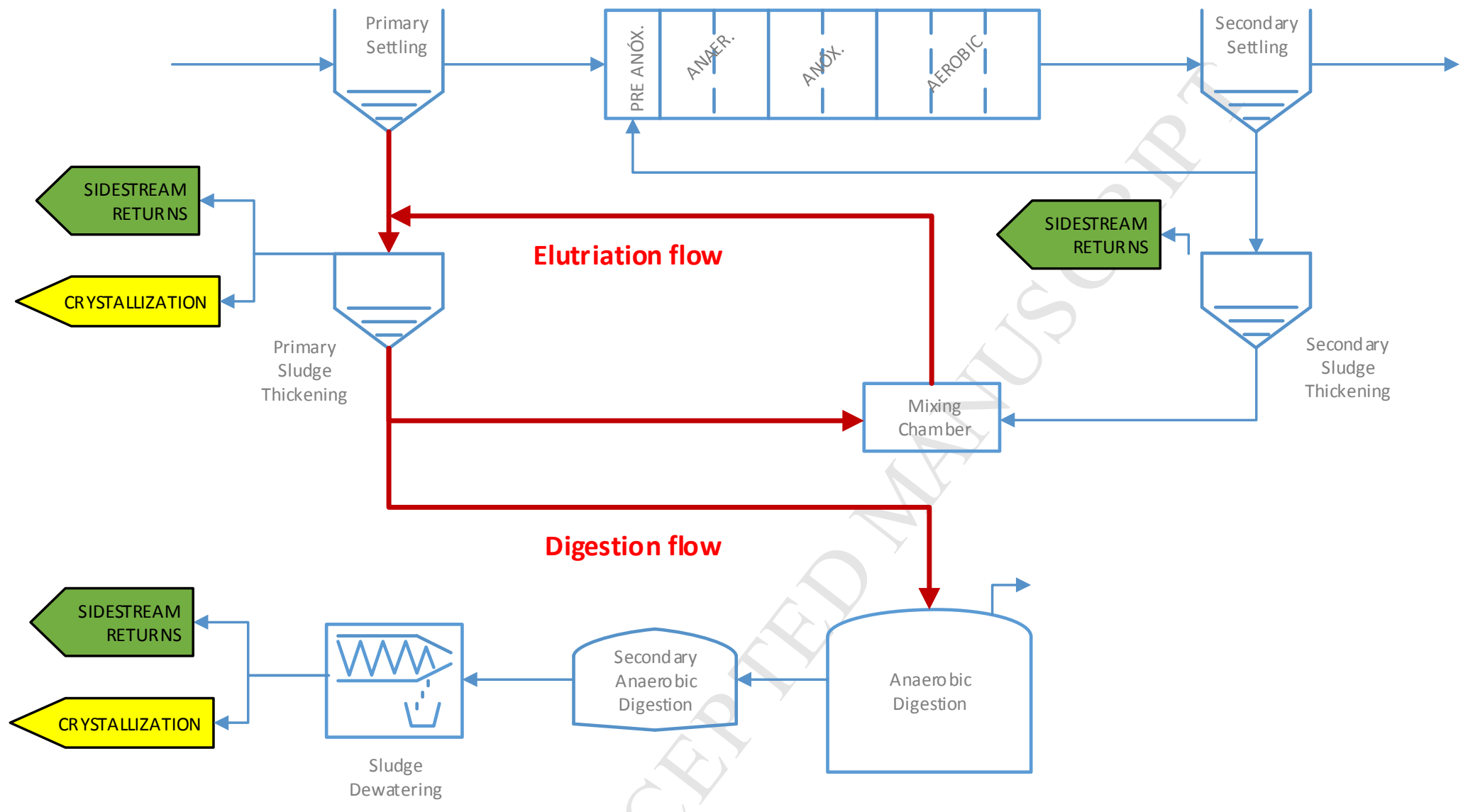




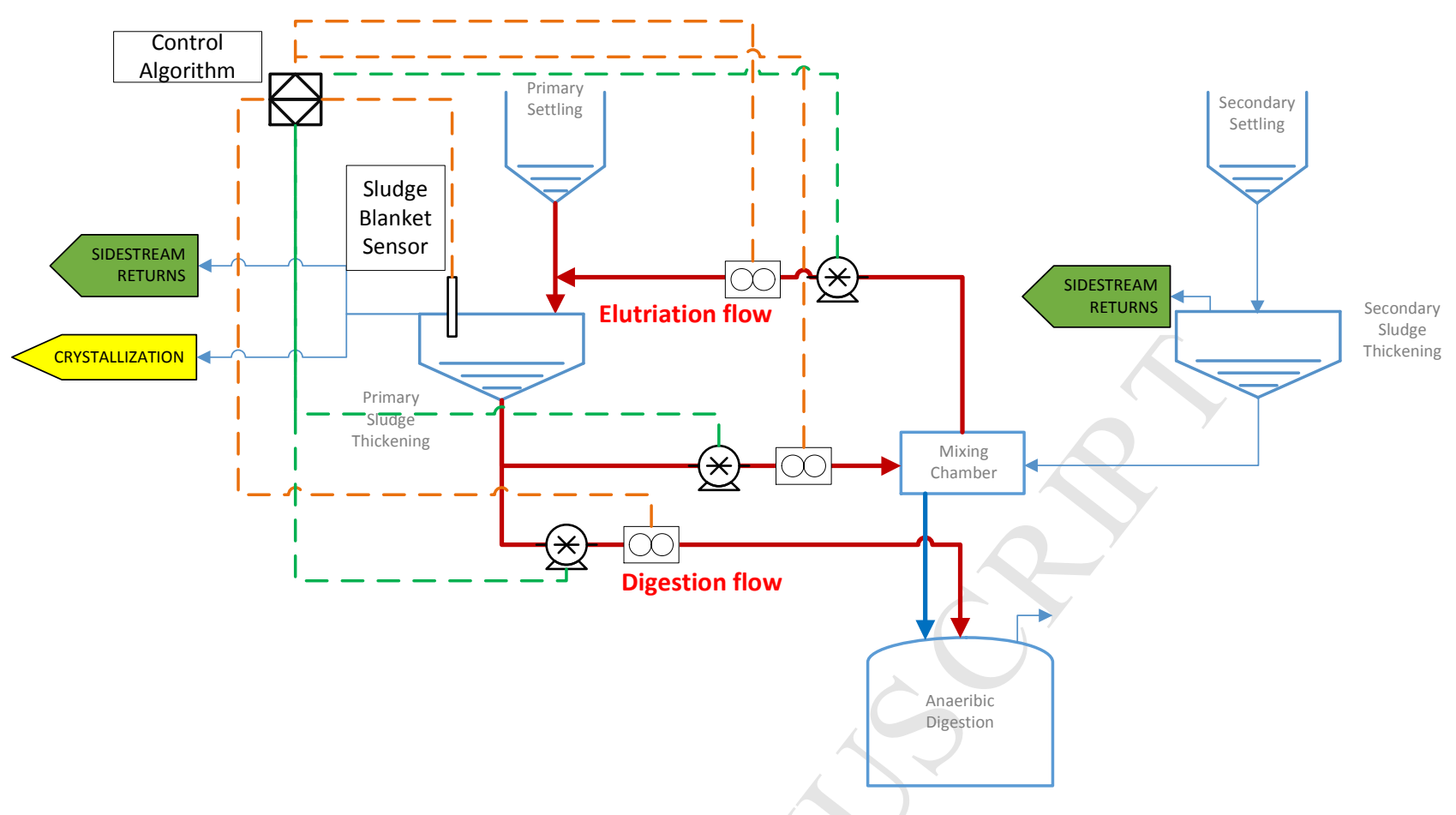




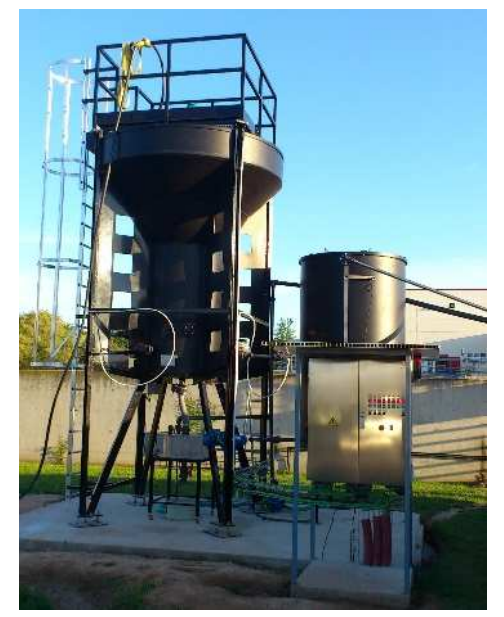

(a)

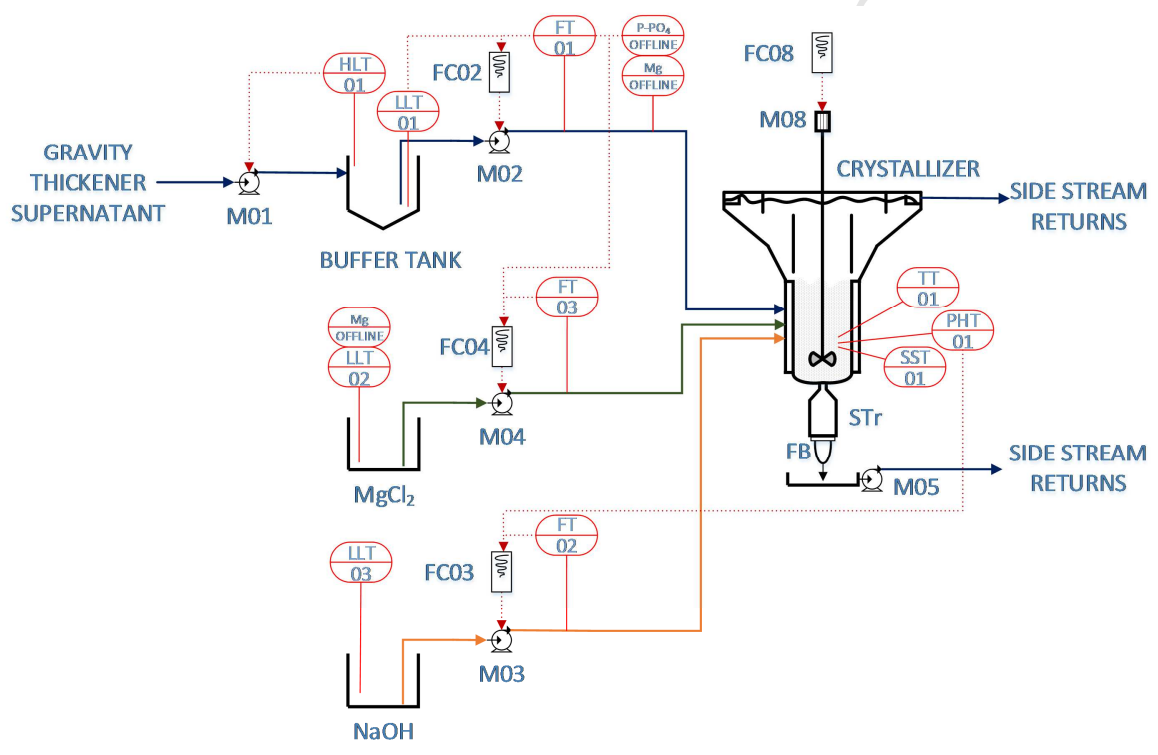

(b) 


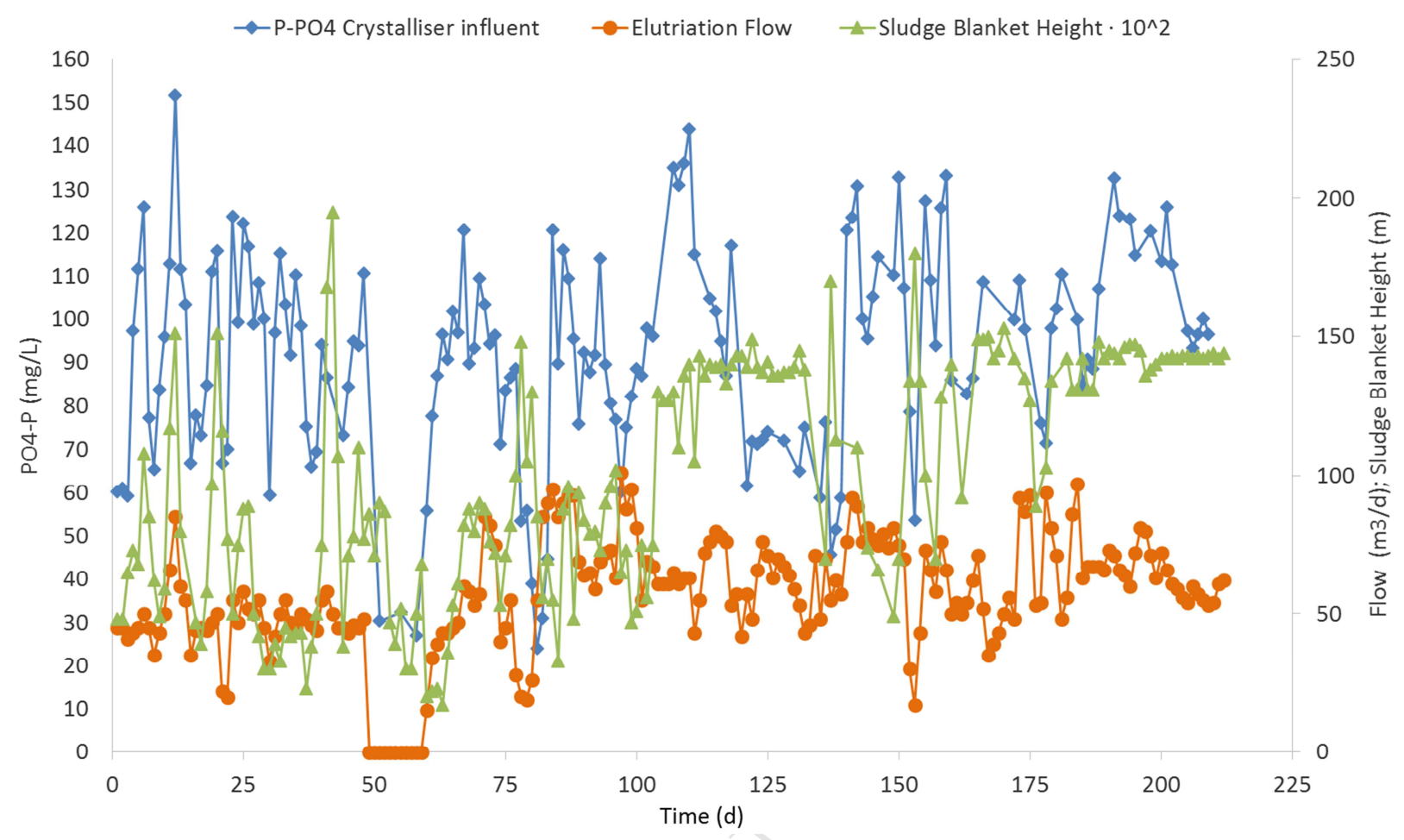

(a)

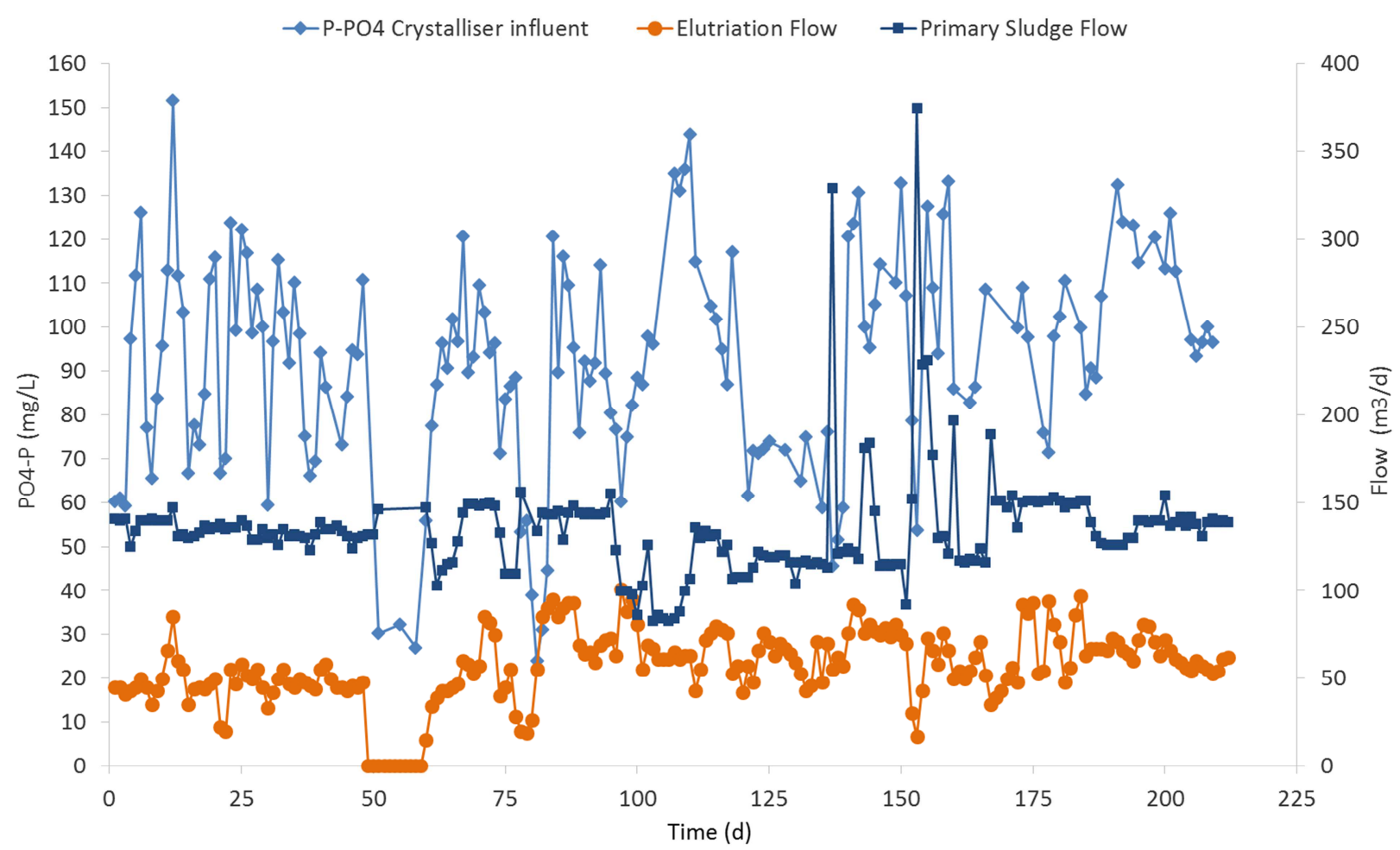

(b) 
- The new sludge line configuration in WWTP reduces P precipitation in digesters by $43 \%$.

- About $103 \mathrm{~kg} / \mathrm{d}(38 \mathrm{t} / \mathrm{y})$ of struvite will be produced with the P-recovery system implemented.

- $19 \%$ of the total P entering the WWTP could be recovered, contributing to reduce P scarcity.

- The revenue of the recovery system implemented is about $4.74 € / \mathrm{kg}$ of $\mathrm{P}$ recovered.

- The struvite obtained would fulfil the requirements for its use as fertiliser. 